\title{
Comparison Between Online Versus Physical Teaching in the Period of Covid-19. A Comparative Cross Sectional Study
}

\section{Sadia Effendi}

Liaquat University of Medical \& Health Sciences

Urooj Bhatti

Liaquat University of Medical \& Health Sciences

Rubina Ahmedani

Liaquat University of Medical \& Health Sciences

Muhammad Nadeem Chohan ( $\nabla$ nadeem.chohan@lumhs.edu.pk)

Liaquat University of Medical \& Health Sciences

\section{Feriha Fatima Khidri}

Liaquat University of Medical \& Health Sciences

Waseemullah Shaikh

Liaquat University of Medical \& Health Sciences

\section{Research Article}

Keywords: Online teaching, classroom teaching, COVID, teaching methods, medical education

Posted Date: February 18th, 2022

DOI: https://doi.org/10.21203/rs.3.rs-1303311/v1

License: (1) This work is licensed under a Creative Commons Attribution 4.0 International License.

Read Full License 


\section{Abstract}

Objective: To compare online versus physical teaching in the period of Covid-19.

Study design: Comparative cross-sectional study

Place and duration of study: Anatomy department in collaboration with physiology department, Liaquat University of medical and health sciences Jamshoro, Pakistan from December 2021 to January 2022

Methods: In this study,the explanatory and correlational methodology was used. The participants wereMBBS/BDS medical studentsof Liaquat University of medical and health sciences Jamshoro, and the sample size was a convenience sample of 246students. After receiving clearance from the ethical review committee of the university, students were recruited through a mobile app (i.e., WhatsApp). They were invited to complete an anonymous online survey using a Google Form, and all gave their informed consent.Counts with percentages were reported for the best teaching method voted by respondents, advantages, and disadvantages of online and physical teaching methods were also assessed. Opinions were compared across groups using the Pearson Chi-Square test.

Results: In the present study there were two hundred forty-six samples surveyed among them $74.8 \%$ voted the physical teaching, $12.2 \%$ voted for online teaching and $6.5 \%$ elected both kinds of teaching methods, whereas $6.5 \%$ did not vote for any teaching method as the best teaching method.

Conclusion: We concluded that the majority of our students like and favor the physical teaching method as compared to the online teaching method.

\section{Introduction}

The SARS-CoV-2 virus is the causative organism for Corona disease ${ }^{1}$. It causes respiratory distress, fever, cough, and sometimes gastrointestinal manifestations ${ }^{2}$. Although corona disease was evident for a longer period nowadays it became pandemic. The severity of features varies from mild to severe. As the teaching activities are affected all over the world, ${ }^{3}$ online teachingsare becoming popular as an alternate method. Preventive measures are adopted by the government inthe education sector, for preventing person-to-person contact through online teaching ${ }^{4}$. As a result of the COVID 19' pandemic, the entire landscape of education is changed ${ }^{5}$. The notion of distance education and online learning has emerged as a necessity that raises questions about its usefulness.

This study compares the effectiveness of online versus traditional learning. When comparing the two, the most obvious difference is concerned with the perceived lack of human interaction, which is not possible. The foremost method to translate this phrase would be no physical interaction for online learning, whereas classroom learning constitutesphysical interactions with the instructor and the student, online learning transits this element into the physical environment ${ }^{6}$. Physical education has a considerably 
greater influence on a student's personality and cognitive abilities, allowing the student to better confront the teacher and get good test results.

The main goal of this study was to find out the thoughts of our university students about online versus physical education, and how might we improve online teaching to achieve high academic results, if we have to live with the Covid-19 virus for a longer period.

\section{Methods}

This comparative cross-sectional study was conducted from December 2021 to January 2022at the anatomy department in collaboration with the physiology department LUMHS Jamshoro by nonprobability convenience sampling technique. Permission was taken from the ethical review committee of the Liaquat University of medical and health sciences Jamshoro.

During the Covid-19 epidemic, the research was carried out to observe how online versus physical instruction are comparable. The primary goal of this research was to improve online education by taking into account the challenges that our university students face in light of our available resources and determining the most effective teaching style from the perspective of our university students. As a result, the methodology used in this study was explanatory and correlational. The participants wereMBBS/BDS medical studentsof Liaquat University of medical and health sciences Jamshoro, and the sample size was a convenience sample of 246 students. Students were recruited through a mobile app (i.e., WhatsApp), and the study lasted for two months. They were invited to complete an anonymous online survey using a Google Form, and all gave their informed consent.

Data were stored and analyzed using IBM-SPSS version 23.0. Counts with percentages were reported for the best teaching method voted by respondents, Advantages, and disadvantages of online and physical teaching methods were also assessed. Opinions were compared across the group using the Pearson ChiSquare test. P-values less than 0.05 were considered statistically significant. The pie diagram also reported for the vote of best teaching method.

\section{Results}

In the present study, there were two hundred forty-six samples surveyed among them $74.8 \%$ voted the physical teaching, $12.2 \%$ voted for online teaching and $6.5 \%$ elected both kinds of teaching methods, whereas $6.5 \%$ did not vote for any teaching method as the best teaching method. (As mentioned in Pie diagram-1).

Table-1 reports and compares the advantages of the online teaching method. For online teaching $86.7 \%$ said it is the best way to deliver lessons, $90 \%$ said online teaching has the number of tools as part of their lesson plans, $96.7 \%$ said online education allows students to attend classes from any location of their choice, $96.7 \%$ said online lectures can be recorded for further reference, $90 \%$ saidonline teaching is for more affordable as compared to physical learning, $76.7 \%$ said it improves students attendance, and $70 \%$ 
said it is a good wayto create a better learning environment. Among these statements, outcomes on an efficient way to deliver, affordability, attendance, and creation of perfect learning environment givea significant association with another kind of teaching methods $(p<0.01)$.

Table-2 reports the disadvantages of the online teaching method. For online teaching $56.7 \%$ said the inability to focus on the screen for a longperiod, $66.7 \%$ said they are easily distracted by other sites, $73.3 \%$ said the bigger challenge of online classes is internet connectivity, $53.3 \%$ said they feel lonely, $90 \%$ said online classes required training of teachers and $50 \%$ said health hazard due to increase screen time.Statements on inability to focus, internet connectivity, sense of isolation, and health hazard givea significant association with another type of teaching method $(p<0.05)$.

Table-3 reports the advantages and disadvantages of physical teaching methods. For physical teaching all were agreed on physical education provides a healthy environment to students for learning, $97.3 \%$ said it builds the character of a child, $98.4 \%$ said students get the chance of interaction with their subject teacher, $96.7 \%$ said they learn a lot from their peers, $99.5 \%$ said physical education clears the concepts of the students by interacting with their teachers, $97.3 \%$ said it motivates the students to attend their respective institutions, $95.1 \%$ said reward associated with physical education, $92.9 \%$ said it makes the carrier of the students, $97.3 \%$ said physical education provides a sense of competition among students, $58.2 \%$ said physical education taking too much of the students time, $54.3 \%$ said physical education is expensive as compared to online teaching. Pearson Chi-Square test is showing a significant association of all these statements with another kind of teaching method adopted by the respondents $P<0.05$.

\section{Discussion}

In the present study, there were two hundred forty-six samples surveyed among them $74.8 \%$ voted the physical teaching, $12.2 \%$ voted for online teaching and $6.5 \%$ elected both kinds of teaching method, whereas $6.5 \%$ did not vote for any teaching method as the best teaching method. Similar results were there in a local study by Abaid Ullah et al, they found that all the students were facing the same issues with online teaching, whether they were at the school level or university level ${ }^{7}$. Another similar study by Tej Bahadur Karki et al found that a higher number of students responded that physical class was more comfortable than the online class ${ }^{8}$.

A couple of unsimilar studies from Saudi Arabia concluded that the online teaching method was wellreceived, and all participants agreed that online sessions were time-saving and that their performance was improved due to the enhanced utility of time ${ }^{9}$. While in another study online learning was more convenient, as demonstrated by the fact that 28.5 and $31.9 \%$ of the respondents thought that it was much more effective and somewhat more effective, respectively ${ }^{10}$. This difference of opinion is due tothe easy availability of electricity (no-load shedding), internet facility and laptops in their country. The results of an international study indicate that students react differently to online teaching methods, their reaction is based on their proficiency in using online tools, their ability to technically access online courses, and the instructors' manner in conducting learning activities ${ }^{11}$. 
Among samples who voted for online teaching most said it is a better method of teaching, has several tools as part of their lesson plans, allows students to attend classes from any location of their choice, can be recorded for further reference, more affordable as compared to physical learning, improves students attendance, is the good method forcreating a learning environment. An unsimilar study by JuliaYu-Fong Chang et al revealed that dental college students preferred online teaching as compared to physical classroom teaching ${ }^{12}$. This difference may be due to well-trained teachers and the availability of resources in Taiwan for online teaching.

Among samples who preferred online teaching mostly said an inability to focus on the screen for a longperiod, the greater chance for students to easily distracted by social or other sites, bigger challenge of online classes is internet connectivity, feeling of lowliness because students miss their pears, required teachers to have online teaching training and health hazard due to increase screen time, statements on inability to focus, internet connectivity and sense of isolation.In a local study from Lahore Pakistan, school and university students had a lot of problems during online classes. A total of $88 \%$ of students had no internet facility, $65 \%$ of students were not satisfied with the online teaching method and $85 \%$ of students had eyesight issues ${ }^{7}$. Higher Education Commission (HEC) Pakistan stated that teachers and students faced a lot of problems with online learning. Most of the students had noaccess to Wi-Fi or computers ${ }^{13}$. Another similar local study showed that online teaching had an improper study environment, insufficient online study material, no access or slow internet speed, and load shedding problems ${ }^{14} \mathrm{~A}$ study was conducted in private universities of Pakistan, results regarding online teaching were similar to us stating that lack of internet facility, load shedding, financial issues, ear pain due to prolonged use of hand-free/Blue-tooth and unreliable results in assessments were the major problems faced by the students ${ }^{15}$.

Among students who adopted physical teaching; all agreed that physical education provides a healthy environment to students for learning, build the character of a child, get the chance tointeract with their subject teacher, learn a lot from the presence of their peers, clears the concepts of the students by interacting with their teachers, motivate the students to attend their respective institutions, reward associated with physical education, it makes the carrier of the students, provides a sense of competition among students, taking too much of the students time, and is expensive as compared to online teaching. Our results are consistent with an Indian study that showed that the physicalclassroom teaching method is better in understanding, convenience for attending class, notes-taking, visibility, audibility, raising queries ${ }^{16}$.A study from the European country proposed that a lack of proper equipment at home, a lack of proper training for information technology use were among the highest-ranked difficulties during online teaching ${ }^{11}$.

We concluded that the majority of our students like and favor the physical teaching method as compared to the online teaching method.

\section{Declarations}


Ethics approval and consent to participate:

Ethical approval was taken from the ethical review committee of the Liaquat University of medical and health sciences Jamshoro Pakistan

Informed consent was taken from each participant

Consent for publication:

Not applicabl

\section{Availability of data and materials:}

Data is available at the following link

https://docs.google.com/forms/d/1AsuerK2ion7t8Szr0EzFtsUcGimQaaSBrmc8MQKladA/edit

\section{Competing interests:}

None

\section{Funding}

None

Methods were performed in accordance with the relevant guidelines and regulations.

\section{Authors' contributions:}

Sadia Effendi = concept design, data collection, manuscript writing

Urooj Bhatti = concept design, data collection, data analysis, final approval

Rubina Ahmedani, manuscript writing

Muhammad Nadeem Chohan = critical analysis, correspondence, final approval

Feriha Fatima Khidri = data analysis, critical review

Waseemullah Shaikh = data collection, manuscript writing

\section{Acknowledgments:}

Not applicable

\section{References}


1. Gorbalenya, A.E., Baker, S.C., Baric, R., Groot, R.J.D., Drosten, C., Gulyaeva, A.A., Haagmans, B.L., Lauber, C., Leontovich, A.M., Neuman, B.W. and Penzar, D., 2020. Severe acute respiratory syndromerelated coronavirus: The species and its viruses-a statement of the Coronavirus Study Group.

2. Fajar, M. and Padjadjaran, U., 2020. Estimation of COVID-19 reproductive number case of Indonesia. BadanPusatStatistik Indonesia.

3. Sahu, P., 2020. Closure of universities due to coronavirus disease 2019 (COVID-19): impact on education and mental health of students and academic staff. Cureus, 12(4).

4. Marinoni, G., Van't Land, H. and Jensen, T., 2020. The impact of Covid-19 on higher education around the world. IAU Global Survey Report.

5. Jena, P.K., 2020. Impact of pandemic COVID-19 on education in India. International journal of current research (IJCR), 12.

6. Zaharah, Z., Kirilova, G.I. and Windarti, A., 2020. Impact of corona virus outbreak towards teaching and learning activities in Indonesia. SALAM: JurnalSosialdanBudayaSyar-i, 7(3), pp.269-282.

7. Ullah, A., Ashraf, M., Ashraf, S., and Ahmed, S., 2021. Challenges of Online Learning during the COVID-19 Pandemic Encountered by Students in Pakistan. Journal of Pedagogical Sociology and Psychology, 3(1), pp.36-44.

8. Kark, T.B., Mahat, D. and Kandel, D.R., 2021. Effectiveness of Online Class and Physical Class during Covid-19 Pandemic. Nepal Journal of Multidisciplinary Research, 4(1), pp.14-30.

9. Khalil, R., Mansour, A.E., Fadda, W.A., Almisnid, K., Aldamegh, M., Al-Nafeesah, A., Alkhalifah, A., and Al-Wutayd, O., 2020. The sudden transition to synchronized online learning during the COVID-19 pandemic in Saudi Arabia: a qualitative study exploring medical students' perspectives. BMC medical education, 20(1), pp.1-10.

10. AlQhtani, A., AlSwedan, N., Almulhim, A., Aladwan, R., Alessa, Y., AlQhtani, K., Albogami, M., Altwairqi, K., Alotaibi, F., AlHadlaq, A. and Aldhafian, O., 2021. Online versus classroom teaching for medical students during COVID-19: measuring effectiveness and satisfaction. BMC medical education, 21(1), pp.1-7.

11. Korcz, A., Krzysztoszek, J., Łopatka, M., Popeska, B., Podnar, H., Filiz, B., Mileva, E., Kryeziu, A.R. and Bronikowski, M., 2021. Physical Education Teachers' Opinion about Online Teaching during the COVID-19 Pandemic-Comparative Study of European Countries. Sustainability, 13(21), p.11730.

12. Chang, J.Y.F., Wang, L.H., Lin, T.C., Cheng, F.C. and Chiang, C.P., 2021. Comparison of learning effectiveness between the physical classroom and online learning for dental education during the COVID-19 pandemic. Journal of Dental Sciences, 16(4), pp.1281-1289.

13. Ali, N.U., 2020. Students were disappointed with the online teaching system amid COVID19. Retrieved from Daily Times: https://dailytimes. com. pk/587446/students-disappointed-withonline-teaching-system-amid-covid-19.

14. Noor, S., Ali, M.N. and Husnine, S.M., 2020. Performance of Online Classes in Lahore, Pakistan during Covid-19. Performance Improvement, 59(9), pp.33-42. 
15. Tabassum, F., Akram, N. and Moazzam, M., 2022. Online Learning System in Higher Education Institutions in Pakistan: Investigating Problems Faced by Students During the COVID-19 Pandemic. International Journal of Web-Based Learning and Teaching Technologies (IJWLTT), 17(2), pp.1-15.

16. Chopra, J., Rani, A., Chopra, S., Manik, P. and Singh, R.R., 2021. The transition from physical to virtual classroom amidst COVID-19 crisis: Analyzing students' perspective to drive improvement in the current online teaching methodology. Journal of Education and Health Promotion, 10.

\section{Tables}

Table 1: Comparison of Online Teaching Method Advantages with choice of teaching Method

\begin{tabular}{|c|c|c|c|c|c|}
\hline $\begin{array}{l}\text { Statements on Advantages of Online } \\
\text { Teaching Method }\end{array}$ & $\begin{array}{l}\text { None } \\
(n=16)\end{array}$ & $\begin{array}{l}\text { Online } \\
(n=30)\end{array}$ & $\begin{array}{l}\text { Physical } \\
(n=184)\end{array}$ & $\begin{array}{l}\text { Both } \\
(n=16)\end{array}$ & $\begin{array}{l}\mathrm{p}- \\
\text { value }\end{array}$ \\
\hline & $\mathrm{n}(\%)$ & $\mathrm{n}(\%)$ & $\mathrm{n}(\%)$ & $\mathrm{n}(\%)$ & \\
\hline $\begin{array}{l}\text { It is efficient way to deliver lessons to } \\
\text { students }\end{array}$ & $6(37.5)$ & $26(86.7)$ & $52(28.3)$ & $12(75)$ & $<0.01^{*}$ \\
\hline $\begin{array}{l}\text { Online teaching has number of tools as } \\
\text { part of their lesson plans like videos, PPTs } \\
\text { etc }\end{array}$ & $11(68.8)$ & $27(90)$ & 165(89.7) & 15(93.8) & 0.07 \\
\hline $\begin{array}{l}\text { Online education allows to attend classes } \\
\text { from any site }\end{array}$ & 13(81.3) & 29(96.7) & $155(84.2)$ & 15(93.8) & 0.21 \\
\hline It can be recorded & 13(81.3) & 29(96.7) & $160(87)$ & $14(87.5)$ & 0.39 \\
\hline It is more affordable & $8(50)$ & $27(90)$ & $78(42.4)$ & $11(68.8)$ & $<0.01^{*}$ \\
\hline It improves student attendance & $7(43.8)$ & $23(76.7)$ & $68(37)$ & $12(75)$ & $<0.01^{*}$ \\
\hline It creates better learning environment & $3(18.8)$ & $21(70)$ & $23(12.5)$ & $8(50)$ & $<0.01 *$ \\
\hline
\end{tabular}

${ }^{*} \mathrm{p}<0.05$ was considered statistically significant using Pearson Chi Square test

Table 2: Comparison of Online Teaching Method disadvantages with choice of teaching Method 


\begin{tabular}{|c|c|c|c|c|c|}
\hline $\begin{array}{l}\text { Statements on Disadvantages of Online } \\
\text { Teaching Method }\end{array}$ & $\begin{array}{l}\text { None } \\
(n=16)\end{array}$ & $\begin{array}{l}\text { Online } \\
(n=30)\end{array}$ & $\begin{array}{l}\text { Physical } \\
(n=184)\end{array}$ & $\begin{array}{l}\text { Both } \\
(n=16)\end{array}$ & $\begin{array}{l}\text { p- } \\
\text { value }\end{array}$ \\
\hline & n (\%) & $\mathrm{n}(\%)$ & $\mathrm{n}(\%)$ & $\mathrm{n}(\%)$ & \\
\hline $\begin{array}{l}\text { Inability to focus on screen for longer } \\
\text { period of time }\end{array}$ & $10(62.5)$ & $17(56.7)$ & 169(91.8) & 13(81.3) & $<0.01 *$ \\
\hline More chance of easy distraction & $12(75)$ & $20(66.7)$ & $155(84.2)$ & $12(75)$ & 0.11 \\
\hline $\begin{array}{l}\text { Bigger challenge of online classes is } \\
\text { internet connectivity }\end{array}$ & 11(68.8) & 22(73.3) & 176(95.7) & 13(81.3) & $<0.01 *$ \\
\hline $\begin{array}{l}\text { Feeling of isolation because students miss } \\
\text { their pears }\end{array}$ & $9(56.3)$ & $16(53.3)$ & $145(78.8)$ & $12(75)$ & $<0.01 *$ \\
\hline Teachers need training for online teaching & $12(75)$ & $27(90)$ & 168(91.3) & 14(87.5) & 0.22 \\
\hline $\begin{array}{l}\text { Health hazards due to increased screen } \\
\text { time }\end{array}$ & $12(75)$ & $15(50)$ & $167(90.8)$ & $12(75)$ & $<0.01^{*}$ \\
\hline
\end{tabular}

${ }^{*} \mathrm{p}<0.05$ was considered statistically significant using Pearson Chi Square test

Table 3: Comparison of Physical Teaching Method Advantages \& Disadvantages with choice of teaching Method 


\begin{tabular}{|c|c|c|c|c|c|}
\hline $\begin{array}{l}\text { Statements on Disadvantages of Online } \\
\text { Teaching Method }\end{array}$ & $\begin{array}{l}\text { None } \\
(n=16)\end{array}$ & $\begin{array}{l}\text { Online } \\
(n=30)\end{array}$ & $\begin{array}{l}\text { Physical } \\
(n=184)\end{array}$ & $\begin{array}{l}\text { Both } \\
(n=16)\end{array}$ & $\begin{array}{l}\mathrm{p}- \\
\text { value }\end{array}$ \\
\hline & $\mathrm{n}(\%)$ & $\mathrm{n}(\%)$ & $\mathrm{n}(\%)$ & $n(\%)$ & \\
\hline $\begin{array}{l}\text { Physical education provides the healthy } \\
\text { environment to students for learning }\end{array}$ & $10(62.5)$ & 16(53.3) & 184(100) & 13(81.3) & $<0.01^{*}$ \\
\hline It builds the character of a child & $8(50)$ & $22(73.3)$ & 179(97.3) & 15(93.8) & $<0.01 *$ \\
\hline $\begin{array}{l}\text { Students get the chance of interaction with } \\
\text { their subject teacher }\end{array}$ & $9(56.3)$ & $23(76.7)$ & 181(98.4) & $14(87.5)$ & $<0.01^{*}$ \\
\hline Students learn more with their pears & $9(56.3)$ & $18(60)$ & 178(96.7) & 13(81.3) & $<0.01 *$ \\
\hline $\begin{array}{l}\text { Physical education clears the concepts of } \\
\text { the students by interacting with their } \\
\text { teachers }\end{array}$ & $6(37.5)$ & 16(53.3) & 183(99.5) & $16(100)$ & $<0.01^{*}$ \\
\hline $\begin{array}{l}\text { It motivates the students to attend their } \\
\text { respective institutions }\end{array}$ & $6(37.5)$ & 19(63.3) & 179(97.3) & $12(75)$ & $<0.01^{*}$ \\
\hline $\begin{array}{l}\text { Rewards associated with physical } \\
\text { education }\end{array}$ & $6(37.5)$ & $11(36.7)$ & $175(95.1)$ & $12(75)$ & $<0.01^{*}$ \\
\hline It makes the carrier of the students & $6(37.5)$ & 16(53.3) & 171(92.9) & $14(87.5)$ & $<0.01 *$ \\
\hline $\begin{array}{l}\text { Physical teaching provides a sense of } \\
\text { competition among students }\end{array}$ & $9(56.3)$ & $24(80)$ & 179(97.3) & $14(87.5)$ & $<0.01^{*}$ \\
\hline $\begin{array}{l}\text { Physical education taking too much of the } \\
\text { students time }\end{array}$ & $5(31.3)$ & $29(96.7)$ & $107(58.2)$ & $12(75)$ & $<0.01^{*}$ \\
\hline $\begin{array}{l}\text { Physical education is expensive as } \\
\text { compare to online teaching }\end{array}$ & $5(31.3)$ & $27(90)$ & $100(54.3)$ & $11(68.8)$ & $<0.01^{*}$ \\
\hline
\end{tabular}

${ }^{*} p<0.05$ was considered statistically significant using Pearson Chi Square test

\section{Figures}




\section{Vote the best teaching method $(n=246)$}

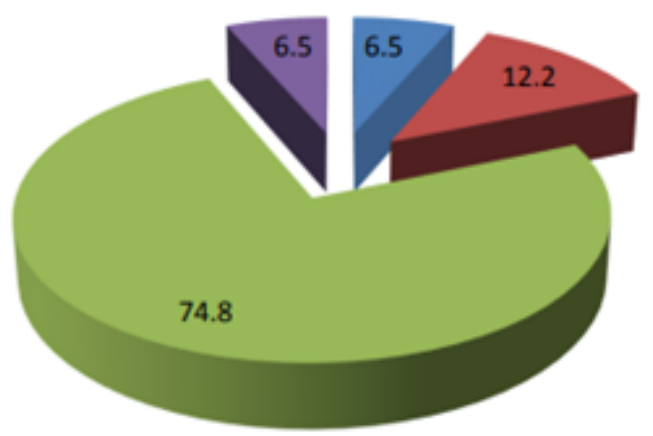

$$
\begin{aligned}
& \text { None }(n=16) \\
& \text { Online Teaching }(n=30) \\
& \text { Physical Teaching }(n=184) \\
& \text { Both Online and Physical }(n=16)
\end{aligned}
$$

Figure 1

Vote the best teaching method

\section{Supplementary Files}

This is a list of supplementary files associated with this preprint. Click to download.

- DatafileDUB.sav 